\title{
National Culture and Research and Development Activities
}

João Pedro Couto, University of the Azores José Cabral Vieira, University of the Azores

ABSTRACT: This paper examines the effect of national culture on the process of innovation and research and development activities in the subsidiaries of multinational companies. For this purpose, we use a sample of 222 subsidiaries for five European countries. The paper has drawn up two important findings. Firstly, cultural dimensions such as individualism, masculinity, power distance and uncertainty avoidance influence research and development activities of the subsidiaries. Secondly, the type of management model, defined according to the location of the parent company, influence the organization of the research and development activities.

\section{INTRODUCTION}

The global context in which firms develop and implement business strategies has changed significantly. The knowledge-based economy has made multinational companies increase the transfer of innovation processes to their foreign subsidiaries in order to adapt their products and services to local needs and to make use of the knowledge locally available. The initiatives to optimise the innovation capabilities and obtain competitive advantages have led to a research and development effort at the subsidiary level. Indeed, the benefits of decentralized $R \& D$ have been mentioned in Pearce (1997), Birkinshaw (2000), Holm and Pederson (2000), Jones and Davis (2000) and Birkinshaw and Hood (1997, 1998a, 1998b).

This paper builds on the responses of subsidiaries' managers and analyses R\&D activities of the subsidiaries of multinational companies (MNC). The relationship of these activities with the culture of the host country and the management model, provided by the geographic origin of the multinational company, is explored. In order to analyse these relationships, we use a data set collected from a survey sent to MNC's

João Pedro Almeida Couto is Professor of Management in the Department of Economics and Management at University of Azores, coordinator of the MBA Program and lectures the courses of Strategic Management and International Business. Email: jpedro@notes.uac.pt Web Page: http://www.uac.pt/ jpedro José Cabral Vieira is an assistant professor of Economics in the Department of Economics and Management of the University of the Azores. His primary research interests include applied econometric analysis, international economics and labour economics. Email: josevieira@notes.uac.pt Web Page: http://www.uac.pt/ cvieira 
subsidiaries in five European countries: Germany, France, Sweden, United Kingdom and Portugal.

The results allow us to establish two findings. Firstly, cultural dimensions influence research and development activities at the subsidiary level. In particular, the

(1) higher the uncertainty avoidance and

$\simeq \quad$ individualism and the lower the power distance and masculinity indexes the

$\omega$ higher the level of research and

( ) development activities performed.

(1) Secondly, the type of management

$\subseteq$ model influences the organization of

os research and development activities

$\rightarrow$ of the subsidiaries. These results contribute to this field of research by gathering empirical evidence that sustains and integrates national culture relations and R\&D.

\section{LITERATURE REVIEW}

There exists a wide and growing body of references in the literature regarding the multinational firm motivations to internalise $R \& D$, the decentralization process and its relation to location advantages (e.g., Casson and Singh, 1993; Pearce, 1989; Cantwell, 1989; Teece, 1976;

(1) Ronstadt, 1978).

The location of R\&D can be attributed to various motives: (1) drivers for the internationalisation process; (2) firm's geographic orientation in R\&D activities; (3) strategic role of the foreign subsidiary (see Casson and Singh, 1993; De Meyer, 1992, 1993; Dunning and Narula, 1995; Cantwell, 1992). The R\&D activities of subsidiaries can be very different. They can range from the role of receiver of technology from other locations of the multinational network, to an adaptive role to local needs, or an autonomous activity (Davis, 2000; Pearce, 1997; Taggart, 1997).

In the context of the subsidiary strategy, the role of the subsidiary's manager in developing initiatives and the relation with the affirmation of $R \& D$ capability, has been focused on various studies (Birkinshaw and Hood, 1998a, 1998b, 1997; Holm and Pedersen, 2000). In this sense, the importance of $R \& D$ has been mentioned as a key factor to the determination of the subsidiary's strategic role (Forsgren et al. 1992; Kogut and Zander, 1993; Dunning, 1992; Papanastassiou and Pearce 1996, 1997). The influence of national culture on the development of R\&D activities is normally related to Hof stede's (1987) cultural dimensions and has been associated with the processes of invention and innovation (Shane, 1992, 1993) and new product development (Nakata and Sivakumar, 1996; Morris et al. 1994).

The Hofstede's (1987) cultural dimensions are five. The first dimension is "power distance" defined as the level of acceptance of an uneven distribution of power in the society. The second indicator is "individualism" which is defined as the importance of the individual as compared with collective goals and efforts. The third indicator is "masculinity" defined as the level of assertiveness that is promoted in the national culture by either gender. The fourth indicator is "uncertainty 
avoidance" which is related to the level of uncertainty with regards to future events that people from a specific national culture are willing to accept. Altogether, these indicators seem suitable to classify and distinguish national cultures. Hofstede also developed a fifth indicator in order to distinguish oriental cultures from the occidental counterparts, which is designated by Confucianism. This indicator relies on the importance of honour, virtue and the recognition of group values.

The influence of local culture on innovation and its importance to $R \& D$ competitive advantages has also been pointed out by Nakata and Sivakumar (1996), when they refer that implicit in the selection of any location is the selection of a national culture.

Several studies on the relationship between cultural dimensions and innovation activities have been conducted by Kedia et al. (1992), Morris et al. (1994), Nakata and Sivakumar (1996) and Shane (1992, 1993). These studies have suggested that low power distance and uncertainty avoidance and high masculinity and individualism can foster higher innovation, thus confirming Hofstede (1987) statement that societies with lower power distance and lower uncertainty avoidance exert a positive influence on innovation.

A global framework which integrates these factors is proposed by Jones and Davis (2000), who established a classification of the role of R\&D for the subsidiaries based on contingency factors. The roles range from: locally-oriented support and adaptation; locally-oriented R\&D; globally-oriented R\&D; competitor market/technology scanning; to other non-technologically related roles.

They relate these roles to the contingency factors such as the type of motivation, geographic orientation, and R\&D mission and establish a theoretical relationship with Hofstede's cultural dimensions. According to these authors the differentiation from locally-oriented support and adaptation to a globallyoriented $\mathrm{R} \& \mathrm{D}$, means a change from high power distance, uncertainty avoidance and masculinity to a lower level of these indicators. The individualism would change from low to high and the Confucian dynamism would remain positive in all technological roles.

Based on these studies we consider that the relation between national culture and research and development can be critical and that there can be advantages from national cultures to specific phases of the process which we evaluate on the following hypotheses.

\section{HYPOTHESES}

In this paper we put forward two hypotheses: a first, regarding the effect of cultural dimensions on the R\&D of the subsidiary; and second, concerned with the influence of the management model of the multinational firm on $R \& D$ activities of the subsidiaries.

In hypothesis one it is stated that: the national cultural dimensions influence the $R \& D$ activities of the 
subsidiaries.

This first hypothesis relies on vast literature related to the definition of the national culture where the works of Hofstede (1987), Ronen and Shenkar (1985), Trompenaars (1994), or Schneider and Barsoux (1997) are included. On the other hand, the

(1) features of the technology and

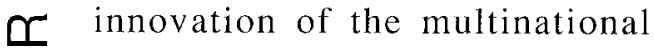
company have been stressed by $\boldsymbol{\omega}$ authors like Forsgren at al. (1992), ( K Kogut and Zander, (1993), Dunning, (1) (1992), Papanastassiou and Pearce $\subset \quad(1996,1997)$.

The technological capabilities have been considered as a key factor to the definition of strategic roles of the subsidiaries by Forsgren et al. (1992); Kogut and Zander (1993);

$\sigma$ Birkinshaw and Hood (1997);

$\subset$ Dunning (1992); Dunning and Narula

O (1995); De Meyer (1993);

־ Papanastassiou and Pearce (1996, ( 1997),

The relation of national culture to $R \& D$ can occur in two different aspects: first, the process of interdepartment cooperation and; second, the propensity for incremental versus radical innovation. These aspects have to do with the element of conflict and risk that are involved in the process of innovation and could be favoured by cultural adaptation. Roure (2001),

The relationship involved in the cooperation process needed in $R \& D$ can be found related to information availability (Brown and Eisenhardt, 1995); pluralism needed to better problem solving solutions (Albach, 1994); and competitive development (Hauptmann and Hirji, 1996). Marquis
(1969) already stated the idea that there is a need for cooperation between the forces of "technology push" and the "market pull". Empirical research shows that cooperation is needed between the various departments (Souder, 1987; Ayers et al. 1997). The process of cooperation inter-functions can be resumed by the aspects of open communication, a feeling of interdependence; the capacity to manage conflicts; the level of cohesion and a focus on the competitiveness with the outside environment. (Henke, 1993; Thamhain, 1990; Gladstein, 1984 , Pinto and Pinto, 1990). The link between these aspects of interfunction cooperation and national culture are associated with the question of individualism and versus collectivism. This can be related with the importance of more group decisions (Hall and Hall, 1984, 1990) that are present German companies, and the more individualistic approach of personal contribution in French companies (Roure, 2001).

A second aspect of R\&D that can be related to national culture is the manner innovation is produced. In fact, the aspect of uncertainty avoidance can be determinant on the fact that a subsidiary develops a more radical research or more development. If the new characteristics of a product are of the most important elements of R\&D (Brown and Eisenhardt, 1995; Cooper, 1994), namely the development of superiority at the eyes of consumers (Cooper and Kleinschmidt, 1987; Song and Parry, 1997), which can 
foster an important competitive advantage (Foster, 1986; Vidal, 1995), still this process is riskier. The level of uncertainty avoidance in Japan and Germany tends to be higher that in Latin countries (Bollinger and Hofstede, 1987). This can be observed by the way German companies develop their business plans. Ali et al. (1993) refer that what can lead to less investment in some product's innovation is the uncertainty of the commercial results of pioneers. The assumption of risk tends to be higher in American companies that in Japanese companies favouring a more radical innovation in America than in Japan.

Another aspect included in these relations between radical innovation and national culture is also the question of individualism. In fact the individualism leads to experimentation and more openness that collectivism (Shane, 1992, 1993). The spirit of competition present in individualistic societies can increase innovation (Herbig and Miller, 1992). The idea of making a difference and make personal contributions are very present in the process of radical innovation and not so much in the process of development.

In the same line of these arguments Hill et al. (1995) reinforce these ideas by recognising that American national culture of individualism and autonomy can undermine the process of reengineering and the innovation process. They state that these aspects, although positive in creation of new products and ideas, are less favorable when it comes to process innovation which is a fundamental element of implementing effective production response for these new products.

The inter-functional barriers and lack of trust common in the American competitive business environment reduce knowledge transfer and the development under intense competitive pressure leads to a culture of speed that is not always favourable to innovation implementation.

Another aspect is the question of national culture and consumer innovativeness developed by Steenkamp et al. (1999). These authors relate a more open perspective of innovations in consumers in countries where the levels of individualism and masculinity are higher. They relate this to more freedom of experimenting and more value on achievement and success. The level of uncertainty avoidance is associated with the presence of a more conservative ambience that tends to reduce experimentation. They also relate these aspects with the national tendency ethnocentrism, but refer that this is moderated by low collectivism.

The fact that experimentation in consumer behavior varies according to national culture elements, leads to the need to develop R\&D in countries where the markets can foster higher levels of response and contribute to the process performance.

In light of these ideas we can argue that an individualist and more risk taking society will tend to produce more radical research, based on cooperation and inter-function communication while a more 
collectivist and uncertainty avoidance society will tend to do better, in developing a concept. This reinforces the element of subsidiary adequacy in $R \& D$ to national culture as an element determinant to the success of the and to the overall multinational R\&D capacity. More specifically, in this hypothesis we consider that the R\&D activities of the subsidiaries are going to be enhanced by their presence in a country that tends to have low power distance, high individualism, low masculinity and low uncertainty avoidance.

Hypothesis two states that: the type of management model of the parent company influences the $R \& D$ activities of the subsidiaries.

The second hypothesis $\sigma$ introduces the type of management $ᄃ$ model of the parent company as a O determinant of the subsidiary R\&D $\mp$ activities. For this purpose, we $\sigma$ consider the classification of the $\subset$ companies into three distinct models, - - according to the proximity of the — parent: a European model, an $\supset$ American and a Japanese model.

The geographic proximity is usually viewed as a determinant of (1) foreign direct investment and can be associated with cultural proximity. In this sense, the Japanese "Kaisha" and the Southeast Asia economies suggest that when compared with Western economies there is more than one way of organizing business activities and that particular institutional environments can promote local adaptations. In terms of market organization, Japanese firms develop a more extensive network of companies, associated with family and loyalty relationships, than the more professional management of the American firms, where activities are managed as "portfolio" with planning and control mechanisms (Whitley, 1992).

While in occidental countries competition is a common form of market organization in the oriental counterparts there are more cooperative efforts with companies relying on mutual dependence, sharing information and developing long-term relations (Orru et al., 1989). In terms of decentralization of functions and authority there is more diversity in American than in Japanese firms. A result of this model is that control is exercised in a more personalized manner and based on personal contact and common values that in formal processes (Kagono, et al. 1985). Calori and De Woot (1994) compared the American and Japanese managers with a distinctive European management model. Despite the diversity of countries in Europe they consider that the approximation to a social perspective of the market economy as well as a more active involvement of the workers in the decision process are distinguishing factors of a European management model. Furthermore, these authors state that American and Japanese companies operating in Europe do not follow this model.

Abramson et al. (1996) made a comparison of Canadian, American and Japanese managers regarding their cognitive process and concluded that Canadians are more theoretical 
orientated, and that Japanese are more long-run oriented than American managers. These authors state that these differences can be important to the type of actions taken, organization design and type of performance indicators selected.

Yip et al. (1997) examined the influence of management processes on the globalisation of industries and the definition of global strategies and concluded that there are significant differences due to national effects. Furthermore, they observe that European and Japanese companies use more global strategies than American companies do. In light of these ideas we consider that the element of national culture is present in $R \& D$ in another manner than the influence of local culture on subsidiary, but in terms on multinational organization.

This view relates national culture to organizational culture and its influence on $R \& D$ is determined by the manner the multinational company deploys its power in relation with the subsidiaries. This hypothesis considers that the more centralized HQSubsidiary relation in Japanese companies will determine that local subsidiaries perform less R\&D and less contribution is derived from local host nations. The American type of management model will tend to be more open and therefore produce more $R \& D$ at subsidiary level. At the reverse of Japanese Multinationals we position European Multinationals. These will tend to be more focused in the gains of local subsidiary R\&D, namely companies from more collectivist and feminine societies that combine these national culture characteristics with moderate uncertainty avoidance and low power distance.

\section{METHODOLOGY OF THE STUDY}

The first step in defining the sample was the identification of Hofstede's indicators that were used to select the countries of this study. The countries selected were United Kingdom, Sweden, Germany, France and Portugal, representing different groups of European nations: AngloSaxonic, Nordic, Germanic, Central Europe and Southern Europe. To identify the countries used in the study, a sample of subsidiaries was taken according to the proportion of foreign subsidiaries existing in each country.

The main data source was a questionnaire sent to the foreign subsidiaries in the selected countries. This questionnaire was directed to the managers of the subsidiaries with the indication that they should themselves supply the information. Otherwise, the questionnaire should be filled by someone involved in the planning processes.

From this questionnaire we obtained information on the location of the parent company in order to determine the management model. With respect to the organisation of activities of research and development the following information was provided to us: $1=$ activity not performed; $2=$ activity performed only to the host country and $3=$ activity performed to several countries. The management 
model was classified as the European model, the American model and the Japanese model.

\section{THE EMPIRICAL MODEL}

(1) dependent variable $(1=$ activity not performed; $2=$ activity performed only

(1) to the host country and $3=$ activity

$\simeq$ performed to several countries) the ordered probit model seems suitable

$\omega$ to explain it. Consider that the

( ) propensity of subsidiary $i$ to choose

(1) (answer) a given alternative is

$\subset$ generated by the following process:

c $I_{i}^{*}=\beta^{\prime} X_{i}+\varepsilon_{i}$ and $i=1,2, \ldots, N$;

$\checkmark$ where $I_{i}^{*}$ is a latent variable, $\beta$ is a set of parameters to be estimated, $X_{i}$ is a set of explanatory variables and $\varepsilon_{i}$ is a random term assumed to

$\widetilde{\sigma}$ be independent and identically

ᄃ distributed $\mathrm{N}(0,1)$. However, $I_{i}^{*}$ is

O not observed in the data but instead

$\mp \quad$ an indicator variable $I$ of the type:

๘

ᄃ $I=1$ if $I^{*} \leq \mu_{o}$

. $I=2$ if $\mu_{o}<I^{*} \leq \mu_{l}$

$\pm I=3$ if $I^{o}>\mu_{1}$

where $\mu_{k}(k=0,1)$ are unknown thresholds to be estimated together

(1) with $\beta$. The probability that a firm

$ᄃ$ chooses a given alternative $j(\mathrm{j}=1,2$,

$\vdash 3$ ) is given by:

$P\left(I=1 / X_{i}\right)=P\left(I^{*} \leq \mu_{o}\right)=$

$P\left(\varepsilon_{i} \leq \mu_{o}-\beta^{\prime} X_{i}\right)=\Phi\left(\mu_{o}-\beta^{\prime} X_{i}\right)$

$P\left(I=2 / X_{i}\right)=P\left(\mu_{o}<I^{*}<\mu_{l}\right)=$

$P\left(\mu_{o}-\beta^{\prime} X_{i}<\varepsilon_{i} \leq \mu_{l}-\beta^{\prime} X_{i}\right)=$

$\Phi\left(\mu_{1}-\beta^{\prime} X_{i}\right)-\Phi\left(\mu_{0}-\beta^{\prime} X_{i}\right)$

$P\left(I=3 / X_{i}\right)=1-P\left(I^{*} \leq \mu_{1}\right)=$
$1-\Phi\left(\mu_{1}-\beta^{\prime} X_{i}\right)$

where $\Phi$ stands for the cumulative standard normal distribution.

The marginal effects of the continuous explanatory variables on the probability that a firm falls into a particular group are then given by:

$\frac{\partial P(I=1)}{\partial X_{f}}=-\left[\phi\left(\mu_{o}-\beta^{\prime} X\right)\right] \beta_{f}$

$\frac{\partial P(I=2)}{\partial X_{f}}=\left[\phi\left(\mu_{0}-\beta^{\prime} X\right)-\phi\left(\mu_{1}-\beta^{\prime} X\right)\right] \beta \beta_{f}$

$\frac{\partial P(I=3)}{\partial X_{f}}=\left[\phi\left(\mu_{l}-\beta^{\prime} X\right)\right] \beta_{f}$

where the subscript $f$ indicates the variable of concern and $\phi$ stands for the standard normal density function. For discrete (dummy) explanatory variables the marginal effects can be calculated through the formula: $\Delta=P(I=j / d=1)-P(I=j / d=O)$, $j=1,2,3$ which yields the marginal effect on the probability when the dummy variable changes from 0 to 1 .

This model can be estimated by maximum likelihood being the loglikelihood function to be maximized written as:

$$
\begin{aligned}
& \log L=\sum_{i-1}^{N} \sum_{j-1}^{3} Z_{i j} \log \left\{\Phi\left(\mu_{j}-\beta^{\prime} X_{i}\right)-\right. \\
& \left.\Phi\left(\mu_{j-1}-\beta^{\prime} X_{i}\right)\right\}
\end{aligned}
$$

where $Z_{i j}$ is an indicator function of the type:

$Z_{i j}=1$ se $i \in j$
$Z_{i j=0}$ se $i \notin j$
$i=1, \ldots, N$
$j=1,2,3$


Since $X_{i}$ includes a constant the parameters are not identified. In order to overcome this problem we set $\mu_{o}=$ O (see Greene, 1998). Furthermore, $\mu_{0-1}=-\infty$ and $\mu_{3}=+\infty$.

\section{ESTIMATION RESULTS}

The percentage of responses to the questionnaire was equal to $23.1 \%$ (see Table 1). We can also verify that the subsidiaries located in Portugal and the United Kingdom were the ones with higher response rates.

Analyzing the distribution of the responses by country we can observe that France was the country with the highest percentage of valid questionnaires $(28.6 \%)$, followed by Germany (26.8\%), United Kingdom $(18.2 \%)$, Portugal (16.9\%) and Sweden $(9.5 \%)$. Given that that the distribution of responses by country do not diverge significantly from the initial setting of the questionnaires, we can consider that the distribution of responses does not undermine the significance of the sample.

The statistics for the average, standard deviation and correlations of the variables can be found in Table 2 .

\begin{tabular}{|lcccc|}
\hline Table $\mathbf{1}$ - Percentages of Answers by Country & \\
Country & $\begin{array}{c}\text { Questionnaires } \\
\text { Received }\end{array}$ & $\begin{array}{c}\text { Questionnaires } \\
\text { Sent }\end{array}$ & $\begin{array}{r}\text { Response } \\
\text { Rate }\end{array}$ & $\begin{array}{c}\text { Percentage } \\
\text { By Country }\end{array}$ \\
United Kingdom & 42 & 170 & $24.70 \%$ & $18.20 \%$ \\
Germany & 62 & 300 & $22.00 \%$ & $26.80 \%$ \\
France & 63 & 290 & $21.40 \%$ & $28.60 \%$ \\
Sweden & 16 & 100 & $22.00 \%$ & $9.50 \%$ \\
Portugal & 39 & 140 & $27.90 \%$ & $16.90 \%$ \\
Total & & & & \\
\hline
\end{tabular}

Table 2-Average, Standard Deviation and Correlations

Descriptive Statistics

1 Individualism

2 Masculinity

3 Power Distance

4 Uncertainty Avoidance

5 Location of Parent

6 Research \& Development
Mean Deviation Correlations

$65.7 \quad 19.1$

$48.3 \quad 19.4-0.45$

$\begin{array}{llll}48.4 & 15.9 & -0.76 & -0.2\end{array}$

$\begin{array}{lllll}68.6 & 25.5 & -0.03 & 0.35 & -0.2\end{array}$

$\begin{array}{llllll}1.9 & 0.8 & -0.1 & -0.3 & 0.12 & 0.12\end{array}$

$\begin{array}{lllllll}1.8 & 0.8 & -0.01 & -0.03 & 0.03 & 0.03 & 0.03\end{array}$ 
As we can see, the more significant correlations are the ones observed between the different Hofstede indicators.

The estimation results are included in Table 3. The null hypothesis that the exogenous variables have no explanatory power

$(1)$ is rejected at the $1 \%$ level, since value of the test (Chi-squared $(6)=79.6)$ is far above the critical value of 16.8 .

The results indicate that the higher the individualism and the uncertainty avoidance indexes the higher the probability of a firm to choose the level 3 (activity performed to several countries) and the lower the probability of choosing the level 1

$\propto$

\section{Table 3: Ordered Probit Model: Estimation Results}

$\omega$

$\omega$

(1)

Constant

Coefficient

$-2.9443$

Standard Error

ᄃ

Individualism

0.0789

$1.1559 *$

Masculinity

$-0.0619$

$0.0173 *$

$-0.1199$

$0.0105^{*}$

power distance

0.1037

$0.0226^{*}$

$\supset$

uncertainty avoidance

$-0.3103$

$0.0204^{*}$

United Statesa 1)

$-1.0966$

0.2296

Japan

1.0637

$0.2454 *$

$\sigma$

$\mu 0$

$-195.1$

$0.1154 *$

$\mp \quad$ Log-L

$-234.9$

Log-L0 (slopes $=0)$

79.6

222

\# of observations

1) Western Europe use as the reference category

* significant at the $1 \%$ level.

\section{Table 4: Ordered Probit Model: Marginal Effects}

Level 1 Level2 Level3

Estimated Probabilities for

the reference category

$0.2978 \quad 0.4052$

0.297

Individualism

$-0.0362$

0.0284

0.0551

$-0.0476$

0.115

0

0.0362

Masculinity

power distance

uncertainty avoidance

0.4165

0

$-0.0284$

$-0.0551$

0

0.0476

United States

$-0.0175$

$-0.0975$

Japan

$-0.171$

$-0.2454$

The reference category has the sample mean of the continuous variables (individualism, masculinity, power distance, uncertainty avoidance) and is located in Europe. 
(activity not performed). The reverse is valid for masculinity and power distance indexes.

Regarding the geographic variables (i.e the management model), United States and Japan have a negative impact on the probability of choosing level 2, as compared with Western Europe (used as the reference category in Table 3 ). However, the difference between Europe and the United States is not statistically significant at $1 \%$ level.

The problem with the interpretation of the parameters of the ordered probit model is that the signs only indicate the sign of the impact of the corresponding variable on the probabilities of the lowest and the highest levels of the scale. In order to overcome this shortcoming and determine the effects on the intermediate levels (in this case, level 1) it is usual to calculate the marginal effects for a reference category.

Considering the average values of the variables and that the subsidiary is from Europe we can analyse the corresponding marginal effects. From Table 4 we can see that an increase in the levels of individualism and uncertainty avoidance reduce the probability of an average subsidiary to be included in level 1 (activity not performed) and increase the probability of being included in level 3 (activity performed to several countries), such as stated above. The levels of masculinity and power distance have the reverse effect. We find no evidence that these variables have an impact on the level 2 , since any change on them switches the probability straightforwardly between the level 1 and level 3 (see Table 4).

The fact that the parent company is from Japan reduces the probability of being in level 3 and increases the probability of being in level 1 . The same is true in the case of the United States, but in a much smaller degree. This reinforces the idea that Japanese multinationals centralise more their research and development activities than European multinationals. American multinationals align at an intermediate level that does not distinguish them from the European companies, in statistical terms.

\section{DISCUSSION AND CONCLUSIONS}

In this paper we have examined the effect of national culture and the type of management model on research and development activities performed by the subsidiaries of multinational firms. The results support: (1) the confirmation of the hypothesis that the cultural dimensions of the host country influence the type of research and development performed by the foreign subsidiaries; (2) the type of management model, associated with the origin of the multinational company, can also influence the nature of research activities performed by the subsidiaries. At this level, the influence of the Japanese model differs from that of the American and European counterparts. The latter two models are not statistically different.

These results are in accordance with the literature. Jones and Davis (2000) refer that a globally-oriented 
research and development would be associated with a lower power distance, uncertainty avoidance and masculinity and to a higher individualism. This type of association is also made by Shane (1993), Nakata and Sivakumar (1996). The results of the empirical analysis show a relation

(1) between national culture and R\&D in

$\Upsilon$ two levels: first, the relation of national culture of the host country with the $\Theta$ activities of R\&D of the subsidiary

$\boldsymbol{\omega}$ and; second, the relation of national

() culture in the multinational, derived

$\sqsubset$ from the home country's influence on

- $)$ corporate culture. In the first case we can verify that the high level of individualism leads to higher efforts in producing $R \& D$ contributions; the low power distance permits the inter-

$\sigma$ function cooperation and problem $\subset$ solving environment, the low O masculinity leads to a type of more - collaborative effort that seams to be $\sigma$ important to the establishment of $\subset$ organized R\&D at the subsidiary and finally, the high uncertainty avoidance is present showing that $R \& D$ at subsidiary level tends to be more present when subsidiaries develop and improve products to the local market rather than when it's a more radical R\&D contribution.

The fact that multinational companies tend to be influenced by the national culture of the country of origin shows that there is substantial connection in terms of $R \& D$ management between the multinational corporate culture and their home national culture. This is referred by Bartlett and Ghoshal (1989), who associate this type of organization to historical heritage, being characterized by centralization of capitals, resources and responsibilities and giving less freedom to create new products and define strategies by the local subsidiaries. This is an aspect that must be understood by multinational management in order to fully respond to R\&D challenges. It is reasonable to argue that in some cases multinational management does not identify this type of problem as a limitation to company competitiveness.

As practical implications of this study we must highlight the following three levels: (1) management of the multinationals (2) management of the subsidiaries and (3) local governments. In the case of multinational management it is important to consider when choosing a location for the subsidiary that national culture has an impact on the results of research and development. The absence of this variable can reduce the understanding of why certain initiatives are more successful that others due to location. In the case of the managers of the subsidiaries, the knowledge of the influence of national culture on $R \& D$ can help them orient their efforts. In the case of local governments, this relationship between national culture and research and development activities can represent an additional argument to attract foreign investments to certain countries.

As questions requiring further research and in order to overcome some of the drawbacks of this study, we can point out the use of a broader 
sample of subsidiaries including other countries with a wider number of regions which could also allow for an evaluation of the effects of Confucianism.

\section{REFERENCES}

Abramson, N. R., Keating, R. and Lane, H. (1996). Cross-national cognitive process differences: a comparison of Canadian, American and Japanese managers. Management International Review, 36, 123-147.

Albach, H. (1994). Culture and Technical Innovation, De Gruyter: Akademie der Wissenschaften zu Berlin.

Ali, A., Kalwani, M.U. and Kovenock, D. (1993). Selecting product development projects: pioneering versus incremental innovation strategies, Management Science, 39.

Ayers, D., Dahlstrom, R., Skinner, S. J. (1997). An exploratory investigation of organizational antecedents to new product success. Journal of Marketing Research, 34, 107-116.

Bartlett, C. A. and Ghoshal, S. (1989). Managing Across Borders: The Transnational Solution. Boston: Harvard Business School Press.

Birkinshaw, J. 2000) Entrepreneurship in the Global Firm. Thousand Oaks: Sage.

Birkinshaw, J. and Hood, N. (1998a). Multinational subsidiary evolution: capability and charter change in foreign-owned subsidiary companies. The Academy of Management Review, 23, 773-85.

Birkinshaw, J. and Hood, N. (1998b). Multinational Corporate Evolution and Subsidiary Development. Houndmills: Macmillan, 268-298.

Birkinshaw, J. and Hood, N. (1997). An empirical study of development processes in foreign-owned subsidiarics in Canada and Scotland. Management International Review, 37, 339-364.

Bollinger, D. and Hofstede, G. (1987). Les differences culturelles dans le management, Les Editions d'Organisation Paris.

Brown Shona L and Eisenhardt K. M. (1995). Product development: past research, present findings and future directions, Academy of Management Review, 20, 343-378

Calori, R. and De Woot, P. 1994). A European Management Model Beyond Diversity. New York : Prentice Hall.

Cantwell, J. (1992) The Internationalization of technology activity and its implications for competitiveness. In O. Grandstrand, L. Hakanson and S. Sjolander (Eds.), Technology Management and International Business. Chichester: John Wiley \& Sons, 75-95.

Cantwell, J. (1989). Technological Innovations and Multinational Corporations. Massachusetts: Basil Blackwell.

Casson, M. and Singh, S. (1993). Corporate research and development strategies: the influence of firm industry, and country factors on the decentralization of $\mathrm{R} \& \mathrm{D}$. Research \& Development Management, 23, 91-107.

Cooper, R.G. (1994). Debunking the myths of new product development, Research Technology Management, July-August, 40-50.

Cooper, R.G. and Kleinschmidt, Elko J. (1987). New Products: what separates winners from losers, Journal of Product Innovation Management, 4, 169-184.

Davis, L. (2000) Multinational research subsidiaries in Denmark. In U. Holm 
and T. Pedersen (Eds.), The Emergence and Impact of $M N C$ Centers of excellence: A subsidiary Perspective. Basingstoke: Macmillan.
De Meyer, A. (1993). Internationalizing R\&D improves a firm's technical learning. Research \& Development, July-August, 42-49.

De Meyer, A. (1992). Management of international $\mathrm{R} \& \mathrm{D}$ operations. In $\mathrm{O}$. Grandstrand, L. Hakanson and S. Sjolander (Eds.), Technology Management and international Business. Chichester: John Wiley \& Sons, 163-179.

Dunning, J. H. (1992 ). Multinational enterprises and the globalization of innovation capacity. In $\mathrm{O}$. Grandstrand, L. Hakanson and S. Sjolander (Eds.), Technology Management and International Business, Chichester: John Wiley \& Sons, 19-49.

Dunning, J. H. and Narula, R. (1995). The $R \& D$ activities of foreign firms in the United States. International Studies of Management and Organization, 25, 39-73.

Dunning, J. H. (1998). Location and the multinational enterprise: a neglected factor? Journal of International Business Studies. 29, 45-66.

Forsgren, M., Holm, H. and Johanson, J. (1992). Internationalization of the second degree: the emergence of European-based centers in Swedish firms. In S. Young and J. Hail (Eds.), Europe and the Multinationals, Alders hot, Hants United Kingdom: Edward Elgar.

Forsgren, M., Pedersen, T. (1998). Centres of excellence in multinational companies: the case of Denmark. In J. Birkinshaw and N. Hood (Eds), Multinational

Corporate Evolution and Subsidiary
Development, New York: St. Martin's, Inc.

Foster, R. (1986). Innovation: the attacker's advantage, New York: Summit.

Gladstein, D.L. (1984). Groups in context: a model of task group effectiveness, Administrative Science Quaterly, 29,499-517.

Greene, W. (1998) LIMDEP V.7 User's Manual, Castle Hill: Econometrics Software Inc.

Hall, E.T. and Hall M.R. (1990). Guide du comportement dans les affaires internationals, Seuil

Hall, E.T. and Hall M.R. (1984). Les differences caches, une étude de la communication internationale, comment communiquer avec les Allemands? Hamburg: Gruner \& Jahr.

Hauptmann O.and Hirji K.K. (1996). The influence of process concourrency of project outcomes in product development: an empirical study of cross functional teams, IEEE Transactions on Engineering Management, 43, 153-164.

Hedlund, G., and Rolander, D. (1990). Actions in heterarchies: new approach to managing the MNE. In C. Bartlett, Y. Doz and G. Hedlund (Eds.), Managing the Global Firm, London: Routhledge.

Henke, J.W., Krachenberg, A.R. and Lyons, T.F. (1993). Cross functional teams: good concept, poor implementation. Journal of Product Innovation Management, 10, 216229.

Herbig, P.A. and Miller, J.C. (1992). Culture and technology: does the traffic move in both directions, Journal of Global Marketing, 6(3), 75-104.

Holm, U. and Pedersen, T. (2000) The Emergence and Impact of $M N C$ Centers of Excellence: A Subsidiary 
Perspective. Basingstoke: Macmillan.

Hofstede, G. (1987) Culture and Organizations: Software of the Mind. New York: McGraw-Hill.

Jones, G. K. and Davis, H. (2000). Implications of national culture on the location of global R\&D. Management International Review, 40, 11-39.

Kagono, T., Alonaka, I., Sakakibara, K. and Okumara A. (1985) Strategic vs Evolutionary Management. Amesterdam: North Holland.

Kedia, B. L., Keller, R. and Julian, S. (1992). Dimensions of national culture and productivity of R\&D units. Journal of High Technology Management, 3,1-18.

Kogut, B. and Singh, H. (1988). The effect of national culture on the choice of entry mode. Journal of International Business Studies, 19, 411.

Kogut, B. and Zander, U. (1993). "Knowledge of the firm and the evolutionary selection: interrelated processes of change. Organization Science, 2(4), 140-145.

Marquis, Donald G. (1969). The autonomy of successful innovations. In Rothberg R. (1981): Corporate Strategy and Product Innovations, The Free Press.

Morris, M.H., Davis, D. and Allen, J. (1994). Fostering corporate entrepreneurship: cross-cultural comparisons of the importance of individualism and collectivism. Journal of International Business Studies, First Quarter, 65-89.

Nakata, C. and Sivakumar, K. (1996). National culture and new product development: an integrative review. Journal of Marketing, 60 (January), 61-72.

Orru, M., Hamilton, G. and Suzuki, M.
(1989). Patterns of inter-firm control in Japanese business. Organization Studies, 10, 549-574.

Papanastassiou, M. and Pearce, R. (1998) Individualism and interdependence in the technological development of MNEs: the strategic positioning of R\&D in overseas subsidiaries. In $\mathrm{J}$. Birkinshaw and N. Hood (Eds.), Multinational Corporate Evolution and Subsidiary Development, New York: St. Martin's, Inc.

Papanastassiou, M. and Pearce, R. (1997). Technology sourcing and the strategic roles of manufacturing subsidiary in the UK: local competences and global competitiveness. Management International Review, 37, 5-25.

Papanastassiou, M. and Pearce R. (1996) The creation and application of technology by MNE subsidiaries in Europe. In F. Burton, M. Yamin and S. Young, (Eds.), International Business an Europe in Transition, London: Macmillan.

Pearce, R.D. (1997) Global Competition and Technolog. Basingstoke, Macmillan

Pearce, R.D. (1989) The Internationalization of Research and Development by Multinational Enterprises. New York: St. Martin's, Inc.

Pinto, M.B. and Pinto J.K. (1990). Project team communications and crossfunctional cooperation in new program development, Journal of Product Innovation Management, 7,200-212.

Porter, M. (1990) The Competitive Advantage of Nations. New York: The Free Press.

Porter, M. (1998). Clusters and the new economics of competition. Harvard Business Review, 76, 77-90. 
Ronen, S. and Shenkar, O. (1985). Clustering countries on attitudinal dimensions: a review and synthesis. Academy of Management Review, $10,435$.

Ronstadt, R.C. (1978). International R\&D: the establishment and evolution of research and development abroad by seven US multinationals.

Shane, S.A. (1993). Cultural influences on national rates of innovation. Journal of Business Venturing, 8 , 59-73.

Shane, S.A. (1992). Why do some societies invent more than others?. Journal of Business Venturing, 7 , 29-46.

Souder, W.E. (1987). Managing New Product Innovations, D.C: Lexington Books.

Steenkamp, Jan-Benedict E.M., Hofstede, F. and Wedel, M. (1999). A crossnational investigation into the individual and national cultural antecedents of consumer innovativeness, Journal of Marketing, 63, 55-69.

Taggart, J.H. (1997). R\&D Complexity in UK Subsidiaries of Manufacturing Multinational Corporations. Technovation, 17, 73-82.

Teece, D.J. (1976) The Multinational Corporation Cost of international Technology Transfer. Cambridge: Ballinger.

Thamhain, H.J. (1990). Managing technologically innovative team efforts toward new product success, Journal of Product Innovation, 7, 5-18.

Trompenaars, F. (1994) Lenterprise multiculrurelle. Laurent du Mesnil: Maxima.

Vidal, Von M. (1995). Strategische pioniervorteile, Zeitschift für Betriebwirtschaft, Ergänzungsheft, 43-58.

Whitley, R. (1992, European Business Systems - Firm and Markets in their National Contexts, London: Sage Publications.

Yip, G. S., Johansson, J. and Roos, J. (1997) Effects of nationality on global strategy. Management International Review, 37, 365-385. 


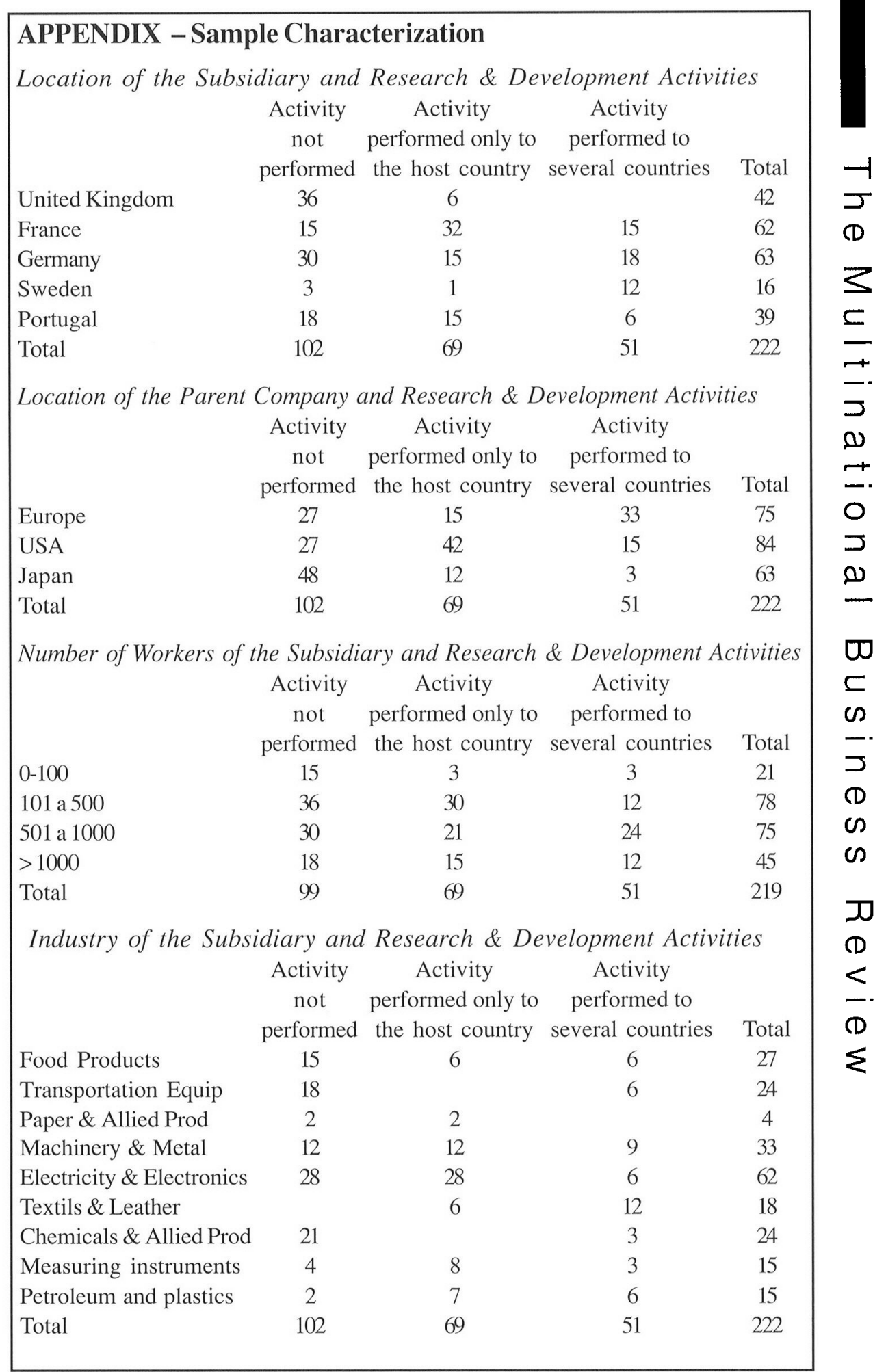

